\title{
Mother's Behavior in Searching for the Health Service of Malnourished Children in Lumut Sub-district, Tapanuli Tengah Regency of 2019
}

\author{
Herida Purba ${ }^{1}$, R. Kintoko Rochadi ${ }^{2}$, Etti Sudaryati $^{2}$ \\ ${ }^{1}$ Master Student in Universitas Sumatera Utara, Medan, Indonesia \\ ${ }^{2}$ Lecturer in Universitas Sumatera Utara, Medan, Indonesia \\ Email: heridapurba366@gmail.com
}

\begin{abstract}
:
This study deals with mother's behavior in searching for the health service of malnourished children in Lumut Sub-district, Tapanuli Tengah Regency of 2019. Mother's behavior in searching for the health services is a form of action taken to maintain the health of their children and to monitor the growth and development of children to grow healthily. The type of research is qualitative research. The study was conducted in several villages in the working area of Lumut Health Center, Lumut Sub-district, and Tapanuli Tengah Regency. The results showed that the lack of knowledge of children mothers due to low maternal education, so that mothers do not understand about malnutrition and the benefits of health care facilities. Low family income factors cause mothers to not provide proper and varied food for the family. Thus the mother only provides sufficient food that can last a long time such as salted fish and boiled fish.
\end{abstract}

Keywords:

mother's behavior; health service; malnourished children

\section{Introduction}

The goal of health development is to increase awareness, willingness, and ability to live healthy for everyone so that optimal health levels are achieved. It is expected that all people behave in healthy lives, and are able to reach quality health services (Ministry of Health, 2017).

Collaboration between cross-sectorial activities and health programs is a determinant of success in national development in the health sector. Improving maternal and child nutrition health, ease of obtaining services and quality of health especially in rural areas, and borders are the goals of the main targets of the 2015-2019 RPJMN (Ministry of Health, Republic of Indonesia, 2017).

The expected healthy behavior of Indonesia in 2025 is proactive in maintaining health and can reduce the impact of an illness and play an active role in public health activities. In addition, the community is expected to be able to reach quality health services and have health insurance. With the realization of healthy living behaviors in achieving quality health services, optimal health degrees are achieved (Ministry of Health, 2017).

The location of this research was conducted in Lumut Sub-district, Tapanuli Tengah Regency, located in North Sumatra Province. Central Tapanuli Regency has 20 Sub-district with 23 health centers. Lumut Sub-district is one of the Sub-district located in the area of Central Tapanuli Regency. Lumut Sub-district has five villages and one urban village located in the southern part of Pandan city or the capital of Central Tapanuli Regency. The total population in Lumut Sub-district in 2018 was 10,699 people, including 5,248 male and 5,421 female (Profile of Lumut Sub-district, 2019). 
Report data from the manager of the Lumut Public Health Center nutrition program in 2016 the number of malnourished sufferers in children in Lumut Sub-district was 15 children, and in 2017 decreased to six children. All infants with severe malnutrition receive treatment. In 2018 the number of sufferers of malnutrition in Lumut Sub-district area is still around six children. The total number of children in Lumut Sub-district area is 1,024 children, 510 female and 514 male children (Profile of Lumut Health Center, 2019).

The work of the people who live in villages near the mountains usually works in the fields as a thief or rubber gum collector. Some of the children left at home do not look after them because mothers have to work in the fields from morning to evening. The average family income from the area is only from the fields. Research conducted by Hidayati \& Suminar (2018), states that the most dominant factor affecting the nutritional status of children is mother's work.

The number of malnourished children children in Lumut Sub-district is located in Lumut Nauli Village by one person, Aek Gambir Village by one person and Lumut Village by four people, one of whom is located at the intersection of three, one person is located at Bandar Mesjid and two others are located at Simarlelan neighborhood that is near the mountains. The diet of children in Lumut Nauli Village and Simarlelan neighborhood near the mountain, that is, the mother only provides durable food such as boiled fish, because the family only once a week to go down to the week to meet family needs because it is caused by the distance between homes and market.

The family's diet in Lumut Village, Bandar Mesjid Village and Simpang Tiga neighborhood and Aek Gambir Village are the same as the people living in Lumut Nauli Village and Simarlelan neighborhood, but some mothers there bring their children to the Integrated Health Post so that the Community Health Center staff or midwives who work in The Integrated Health Post can monitor the growth and development of children and provide knowledge about child nutrition and what needs to be done to meet the nutritional needs of children even with modest food. The results of a study conducted by Susanti, et al (2014) stated that there was a significant relationship between mother's knowledge about nutrition and the nutritional status of children.

Lumut Nauli village does not have a fixed Integrated Health Post schedule, where Integrated Health Post in this area is usually held every two months because of its location far from the Community Health Center. Mother of children who have malnourished children in this place, never bring their children to the Integrated Health Post when the Integrated Health Post is being implemented. When a child is sick the mother takes him to a traditional medicine treatment or to buy medicine from a food stall. As a result of the mothers who did not bring their children to the Integrated Health Post or the place of health care facilities as well as incomplete food intake, resulting in children experiencing nutritional problems so that when the child is sick then they take him to the Integrated Health Post.

\section{Review of Literature}

\subsection{Definition of Behavior}

According to Kwick (1974) in the book Kholid (2017) states Behavior is a form of reaction or action from organisms that can be seen and studied. Behavior in Sarwono's book is interpreted as the result of all forms of human experience and interaction with the 
environment, in the form of knowledge, attitudes and actions or is called a person's response to a stimulus from the outside and from within.

According to a psychologist Skinner (1938) in the book Notoatmodjo (2014) states Behavior is an individual's response to an external stimulus. Therefore human behavior occurs with a process, a stimulus to the organism so that the organism responds, it says the Organism Stimulus Response theory or 'S-O-R'.

Skinner explains the response is divided into two types namely Respondent response or reflexive which means the response occurs due to certain stimuli or eliciting stimulus that can cause responses that are always the same, such as good food can cause the desire to eat. Operant responses are responses that arise and develop, and are then followed by other stimuli.

\subsection{Behavior in Searching for Health Service}

Members of community groups who get the disease, and do not complain about illness, will not take action against the disease, and if they are stricken with the disease and feel complaints, thereby arising form and effort. Notoatmodjo (2014) in his book states the response of individuals when sick is divided into four parts, namely not acting or not doing anything, self-medication, seeking treatment at traditional treatment facilities, and seeking treatment at modern treatment facilities.

Do not act or do nothing. A situation does not interfere with daily activities. Where people assume that without taking action the symptoms they feel will disappear by themselves. There are still more people doing or prioritizing other tasks which according to him are more important than doing self-medication. In addition there is a reason that health facilities are too far away from home, requiring a long time.

The act of self-medicating. The act of self-medication means that the community has trusted themselves, and feels that they can treat themselves based on experience and can heal. Thus outside treatment is no longer necessary for individuals or communities. Seek treatment at traditional treatment facilities. This means that people who live in rural areas, traditional treatment efforts are still preferred over other treatments. People prefer shamans who are considered trusted and can cure their illnesses.

Seek treatment at modern treatment facilities. A treatment effort is made for health care facilities held by the government and private parties, including clinics, health centers, hospitals and other modern medicine. Perceptions or views of community groups about the health of the sick are different from ours about health, where the community's perception of health and illness has a very close relationship with the behavior of seeking treatment services. If the community's perception of health and sickness is not the same as ours, the community does not want to use the recommended health service facilities, and vice versa if the community's perception of health and illness is the same as our concept, it is likely that the recommended facilities will be used (Notoatmodjo, 2104).

\subsection{Nutritional Status}

Nutritional status is a state of the body where the end result is a balance between nutrients that enter the body and their use. The nutritional status of a person can be influenced by several factors including food products which include the amount of food and types of food, the distribution of food or food, acceptability, which means including 
acceptance or rejection of food related including in choosing and preparing food, the existence of restrictions on certain foods, Economic limitations, Food hygiene includes preparation, presentation, and storage, nutritional knowledge, appetite, and passions for certain types of food (Cakrawati \& Mustika, 2014).

The nutritional status of the community is determined by the food consumed daily. This is influenced by the availability of food in the community, food processing systems, food distribution to the community. Nutritional intake greatly determines public health related to the body's immunity against a disease. Other factors that influence the nutritional status of the community are health services, poverty, education, and social culture which can affect the productivity or quality of community resources. Climate change that occurs can affect food security and security, especially for agrarian countries. These conditions can cause damage to food crops and the lack of nutritional content contained in it so that it can affect the nutritional conditions in the community (Cakrawati \& Mustika, 2014).

\subsection{Factors of Malnutrition Occurrences}

The cause of malnutrition explained by Unicef (1998) in Wiyono's book (2016) states that it can be caused by direct, indirect, main causes and root causes.

Direct causative factor: Poor nutritional status occurs because of an imbalance in food intake (quantity and quality), infectious diseases, and due to damage to some functions of the body's organs so that it cannot absorb food substances properly.

Indirect causative factors: Nutritional status is influenced by insufficient food availability in each family, poor parenting patterns, especially how to provide food to children, children are never or rarely monitored growth and development, as well as unclean home environment sanitation and basic health services, making children vulnerable against infectious diseases.

Main problems causing malnutrition: The causes of malnutrition in the main problem include poverty and low levels of education which causes families to not be able to provide adequate food, costs for health services, so that it cannot be reached by the community. From these factors is strongly influenced by the state of an area associated with low employment opportunities and food availability in the market.

The problem root of the cause of malnutrition: The causes of malnutrition that occur at the root of the problem include the existence of economic, political and social crises including the occurrence of disasters, and damage to the network of production, distribution, and sale of food and food, resulting in people not getting enough food intake. In this case the group of children who are most vulnerable due to their limitations, where they have not been able to express themselves hungry or sick.

\section{Research Method}

The type of research is qualitative research, which means that as a method to explore and understand the meaning of a number of individuals or groups of people to be examined (Creswell, 2017). The election with qualitative methods is used as a research method, with the reason to explore or dig deeper and identify problems based on observation and interviews. The purpose of this qualitative study is to understand social phenomena or phenomena by focusing more on a complete picture of the phenomena studied (Martha \& Kresno, 2017). 
Qualitative research has variety of designs. This research wants to dig deeper into the experience of malnourished children' behavior in searching health services. The design model used in this study is phenomenology which aims to explore maternal experiences, regarding maternal behavior in the search for malnourished children health services.

The study was conducted in several villages in the working area of Lumut Health Center, Lumut Sub-district, and Tapanuli Tengah Regency. The selection of the location of this study is because based on the Tapanuli Tengah Regency Health Office Report, it was found that sufferers of malnourished children for three years in a row. Data from the manager of the Lumut Public Health Center Nutrition Program Lumut Sub-district, Tapanuli Tengah Regency in 2018 the number of malnourished children is six children. When the research was conducted from September to June 2019, it began with observations and interviews in several villages in Lumut Sub-district, Tapanuli Tengah Regency.

\section{Discussion}

Integrated Health Post is a form of activity carried out and carried out by and for the community with the aim of empowering the community and providing facilities to the community in obtaining basic services, one of which is monitoring the growth and development of children. Community participation and activity is very important in the implementation of the use of Integrated Health Post services, where mothers who have children are expected to come to Integrated Health Post services which are carried out every month with the aim of knowing the growth and development and nutritional status of children. The results of a study conducted by Kusumayanti \& Busri (2016), stated that there is a relationship between knowledge and attitudes of mothers and the role of cadres to the activity of mothers visiting children coming to Integrated Health Post services.

The implementation of Integrated Health Post activities in the Lumut Sub-district area has not been maximally visited by mothers who have children, where some participants have never come to bring their children to the Integrated Health Post service center, so the growth and development of their children cannot be monitored properly by health workers. Some reasons mothers do not come to Integrated Health Post services such as the distance from home to Integrated Health Post is too far, do not know the Integrated Health Post schedule, no one takes their children to the Integrated Health Post and mothers are too busy working in the fields from morning to evening. This is supported by the results of research conducted by Puspitasari (2014), which states the status of working mothers has a seven-time effect on the participation of mothers of children who come to Integrated Health Post services.

People who live in villages near the mountains in the Lumut District area still have a habit, where when a family member is sick, they will treat it themselves by buying medicine from a food stall and there are also participants saying they bring treatment to a shaman. This is as expressed by several participants as follows:

“...gak pernah saya datang ke posyandu, karena jauh dari rumah kesana, kami tinggal dekat gunung, saya kerja diladang mulai pagi sampe sore, nanti siapa yang bawa anakku ke posyandu, selama ini kalau sakit demam saya obati sendiri, saya kasih obat yang dari warung dan dengan mengusuk kepalanya nanti sudah sembuh. Dulu memang pernah membawa ke dukun untuk berobat karena disuruh keluarga..." (Participant 1) 
“... saya juga tidak pernah ke posyandu atau puskesmas, kalau anakku sakit kuobati sendiri, kubeli obat dari warung nanti, dua hari lagi sudah sembuh. Kalau ke puskesmas jauh tempatnya, uangku gak ada untuk ongkos, makan saja kurang untuk anak-anak di rumah ini, kesana harus naik ojek, aku juga bekerja diladang jadi tidak sempat membawanya kesana..." (Participant 2)

“...gak ada yang menjaga anakku yang laen dirumah nanti kalua pergi ke posyandu, makanya aku jadi gak datang kesana, lagi pula gak tahu saya jadwal posyandunya, kalau sakit beli obat dari pasar saja nanti juga sembuh. Kemarin anakku pernah sakit tarsapo, kata tetangga bawa dulu ke dukun biar cepat sembuh ..." (participant 3)

Health is a requirement of the most basic community groups for human life. To achieve optimal health status, efforts are made to maintain and improve health. One of the programs carried out is Integrated Health Post service activities. Integrated Health Post is one of the promotive efforts aimed at maintaining and improving health while prevention is aimed at preventing people at risk for disease (Syafrudin, 2015). At present there are still mothers who have children who never come to the health service, because the distance from their home to the health service is very far away. This is in line with the results of research conducted by Sartika (2010), which states that the distance of the place of residence of respondents is one of the obstacles in utilizing health services, where the results of bivariate analysis show the proportion of malnutrition events $(\mathrm{BB} / \mathrm{U}, \mathrm{TB} / \mathrm{U}$, and $\mathrm{BB} / \mathrm{TB}$ ) in children is higher in children with a distance of a house above 300 meters with a travel time of more than seven minutes and do not have transportation to the health service and must use other means of transportation such as motorcycle taxi.

There are still family members of informants who are malnourished children who believe in traditional medicines such as traditional healers. During this time people who live near the mountains still believe in shamans and they come for treatment there because of the advice of the family. The low status of public health is also influenced by various interrelated factors namely poverty, environmental conditions, geographical conditions, access to services, education and health level (Syafrudin, 2015). In addition to suggestions from neighbors and family to bring the treatment of the shaman, the mother of children also believes that the treatment to the shaman heal faster and cheaper. This is supported by the results of research conducted by Fanani \& Dewi (2014), stating the factors that are the reason for the community to go to the shaman, namely because of family, personal experience, medical expenses and fast recovery.

The busy mothers of children who work in the fields every day from morning to evening is a factor that may affect the mother not coming to bring her child to the Integrated Health Post to be weighed and monitored for growth. The results of a study conducted by Sulistiyanti \& Untariningsih (2013) stated that the mother's work status is related to the mother's activity in carrying and weighing her children at Integrated Health Post.

Other participants still want to come to Integrated Health Post, although not every month they bring children to be monitored for growth and development. Mothers who come to the Integrated Health Post service center bring their children when providing additional food and when the child is sick. The results of a study conducted by Hildayanti \& Aulia (2017) stated that mothers of children who take advantage of Integrated Health Post service visits are approximately eight times a year having good nutritional status in their children. Here are some participant expressions: 
“...kemarin pernahnya kubawa anakku ke posyandu, tapi jarang memang, waktu itu ada acara posyandu dari puskesmas pembagian makanan tambahan dan susu, jadi kubawa lah anakku kesana sekalian diperiksa karena anakku lagi sakit, disuruh kader supaya datang kesana..."(Participant 4)

“...sejak cucuku sakit, dan badannya mulai kurus sudah kubawa dia ke posyandu karena jarak rumah dengan posyandu yang dibuat di pukesmas dekat, bisa berjalan kaki..."(Participant 5)

Health service activities carried out at Integrated Health Post include the provision of vitamin A, immunization coverage, supplementary feeding and monitoring of infant and children nutrition through weighing and counseling on clean and healthy living and about healthy food for families. The results of research conducted by statistical tests by Reihana \& Duarsa (2012) stated that there was a relationship between supplementary feeding and the participation of mothers of children coming to bring their children to Integrated Health Post.

Good nutrition for children is very important for survival, especially during the process of growth and development. This group of children requires nutrition from daily food in the right amount and good quality. Completeness of the composition of food in one family depends on the ability of the family itself to arrange food, the ability to get the necessary food ingredients and knowledge in arranging food. Family food in rural areas is generally simpler compared to families who live in urban areas. This is due to limited food ingredients, where the distance between the market and people's homes is very far (Moehji, 2017).

Food served by mothers of children in families in Lumut Sub-district who live near the mountains from day to day is a simple meal of rice, boiled fish or salted fish and vegetables. Mothers only provide food that can last a long time at home at an affordable price. The results of research conducted by Puspasari \& Andriani (2017), states that the nutritional status of children is influenced by the mother's knowledge about nutrition and food intake for children (energy, carbohydrates and protein).

Incomplete food intake of nutritional content given by mothers to children, will affect the period of growth and development. Nutritional status is also influenced by food consumed and health conditions, such as nutrients contained in food, availability of supplementary food and health conditions are affected by family purchasing power, maternal beliefs about food and health care and environmental and social conditions (DB Jeliffe, 1976) in the book (Wiyono, 2016). The results of research conducted by Purwaningrum \& Wardani (2012), states that there is a relationship between food intake (energy and protein) and nutritional status of children. The figure below explains that the daily food intake that is given to children with poor nutrition only in the form of boiled rice and vermicelli. 


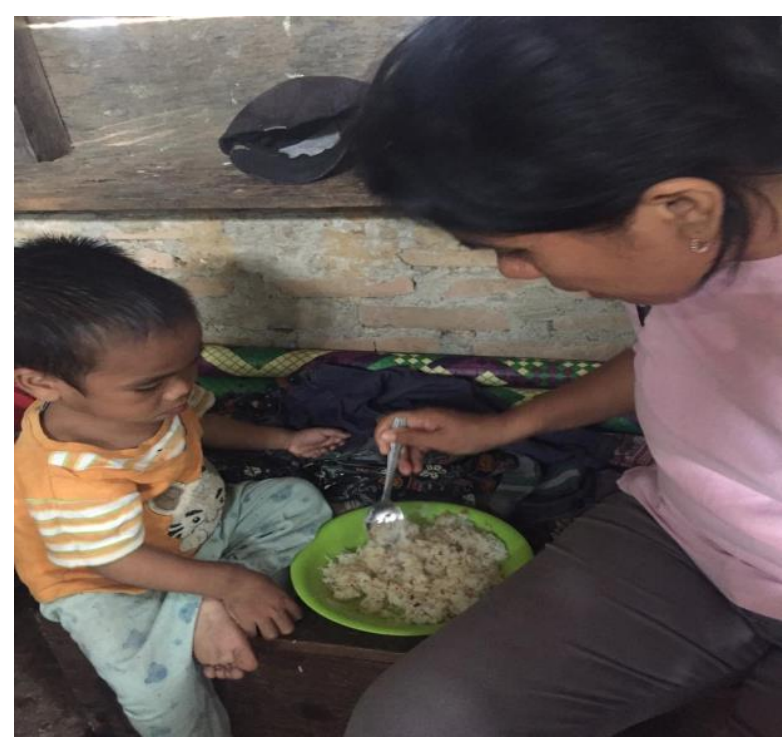

Figure 1. Lunch menu served by the family

Lack of energy and protein intake has an impact on the physical and mental state or intelligence of children, caused by the consumption of food that does not vary (Wiyono, 2016). In addition to this factor, mothers of children are also not active in seeking health information about healthy food due to lack of mother's knowledge. This is in accordance with research conducted by Putri, et al (2015) with the bivariate test showing that there is a relationship between mother's educations, mother's occupation, family income, number of children and parenting with the nutritional status of children.

The work of the people who live in villages near the mountains is mangguris or taking gum from their trees and then collects them for sale on weekends. The level of family income and mother's knowledge is very low resulting in mothers not actively seeking health services for their children. This is supported by the results of research conducted by Mutika \& Syamsul (2018), by conducting in-depth interviews with two key informants and three additional informants, stating there is a relationship between maternal knowledge about nutrition, family income, and the number of family members to nutritional status.

Attitude is a person's closed response to a particular stimulus or object, which already involves the opinion and emotion factors concerned (Notoatmodjo, 2014). Attitudes of mothers of children in seeking health services so far are after their children experience illness. If the child is sick, the mother usually treats it herself by buying medicine from a stall near the house and from the week when she goes shopping there and massages the head of a children with oil. Children who are sick with a fever are usually mothers giving the bodrex medicine, after two days of taking medicine from their children's stalls will recover.

Health service is one of the programs in an effort to improve the optimal degree of public health, meaning that the community is able to maintain and maintain health through the health services available in their respective regions. To achieve health services in accordance with what is desired, it must be considered basic things such as availability, can be achieved, and can be reached, and efficiently (Azwar, 1995). Utilization of health services so far for people who live in mountainous areas is still not optimal, due to many factors that influence it. These factors include the distance between the residents' houses and the place of health care, which is very far, and there are still families who believe to come to the shaman for reasons of lower costs. Here are some participant expressions: 
“...Kalau anakku sakit demam nanti ku oles minyak dikepalanya dan dipijit-pijit, kadang kubawa berobat ke dukun yang adisini..." (Participant 1)

“...Selama ini, kalau anakku sakit tidak langsung kubawa berobat ke puskesmas, kukasih dulu minum obat yang kubeli dari warung, nanti kalau sudah diminumnya dua hari sudah sembuh..."(Participant 2E3)

“...Waktu anakku sakit dulu, kubawa dia berobat ke posyandu supaya diperiksakan bidan disana, sekaligus ada pembagian makanan tambahan waktu itu dan supaya anakku ditimbang juga..."(Participant 4)

The results of research conducted by Aswadi, et al (2018) to 16 informants, showed that mothers' attitudes, actions or family support for the use of Integrated Health Post children are generally lacking, where mothers of children are enthusiastic about coming to Integrated Health Post only because they are called by cadres and officers and vitamin distribution A, additional food and medicine. Matters which include the attitude of mothers in the search for health services are illustrated in the sub-theme of the mother's response to the problem of malnutrition and finding a place of health care.

The form of family participation for mothers since one of the family members is said by the doctor to have malnutrition is to accompany and bring to the place of health care facilities to get treatment. The following participant expressions:

“...kalau membawa ke puskesmas waktu anakku sakit gizi buruk, aku ditemanai suamiku kemarin, anakku ditinggal dulu sama tetangga, tetapi untuk pergi ke pelayanan kesehatan untuk berobat kalau anak saya sakit lagi saya sendiri yang membawa karena dia harus bekerja dilaut. Tetapi kalau pas didarat atau di rumah dia mau menemani..." (Participant 4)

All participants were supported by families in going to seek health services after their children experienced malnutrition. Although not all participants are accompanied by their families, there are also those who are accompanied by neighbors because their husbands are not at home on the grounds of working outside the city and there are those who work at sea. The results of research conducted by Indrayati (2013), states that the type of work and income affects the desire of the community to participate in health services.

The search for health services for severely malnourished children is carried out by bringing their children to Integrated Health Post in village to be weighed and monitored for growth and development. The role of the family, both husband and grandmother, greatly influences the mother in seeking health services, where the family is very needed to play a role in dealing with health problems like this, both in the form of participation in delivering or providing information about health. The results of research conducted by Djamil (2016) state that there is a relationship between knowledge, attitudes and support of families, community leaders, health workers and the support of Integrated Health Post cadres to the mothers' behavior in weighing a child's weight to Integrated Health Post. 


\section{Conclusion}

Mother's behavior in searching for the health services is a form of action taken to maintain the health of their children and to monitor the growth and development of children to grow healthily.

The results showed that the lack of knowledge of children mothers due to low maternal education, so that mothers do not understand about malnutrition and the benefits of health care facilities. Low family income factors cause mothers to not provide proper and varied food for the family. Thus the mother only provides sufficient food that can last a long time such as salted fish and boiled fish.

The reason why mothers have never been to a Community Health Center or Integrated Health Post all this time is because the distance between the house and the health service is too far, there is no money for transportation costs and the mother is busy working in the fields from morning to evening. After the mother found out that her child was suffering from malnutrition, the mother then went to the health service. There are still villages near the mountains where there are currently no health workers, so the implementation of the Integrated Health Post is done once every two months from the Community Health Center. The family supports the mother in seeking health services after learning that her children is suffering from malnutrition and is willing to use health services for further treatment.

\section{References}

Achmadi, U.F. (2014). Kesehatan masyarakat teori dan aplikasinya (Edisi ke-1). Jakarta: PT Raja Grafindo Persada.

Adriani, M., \& Wirjatmadi, B. (2014). Pengantar gizi masyarakat. Jakarta: Prenada Media Group.

Agustina, N.P., Wuryanto, M.R., \& Ratnaningsih, E. (2013). Faktor-faktor yang mempengaruhi ibu balita tidak berkunjung ke Integrated Health Post studi di Desa Pamongan Kecamatan Guntur Kabupaten Demak. Jurnal Kebidanan, 4(1) 1-9.

Awadi, Syahrir, S., \& Adha, A.S. (2018). Perilaku ibu terhadap pemanfaatan pelayanan Integrated Health Post balita di wilayah kerja Community Health Center Tarakan Kecamatan Wajo Kota Makassar. Al-Sihah: PublicHealth Science Journal, 10(1), 12-25.

Hidayati, R., \& Suminar, I.T. (2018). Hubungan karakteristik keluarga dengan status gizi anak balita di Desa Pleret Panjatan Kulon Progo. Naskah Publikasi, 1-19. Diakses dari digilib.unisayogya.ac.id/4417.

Indrayati, R. (2013). Faktor-faktor yang mempengaruhi partisipasi masyarakat dalam pelayanan kesehatan di Pusat Kesehatan Masyarakat Tembilahan Hulu Kabupaten Indragiri Hilir (Tesis, Universitas Terbuka Jakarta). Diakses dari repository.ut.ac.id/1024/1/41368.pdf.

Kadir, S., \& K, Z.U.H. (2016). Analis pelayanan Integrated Health Post dan perilaku ibu terhadap status gizi balita. Jurnal Sainstek, 8(4), 1-10. Diakses dari https://mail.google.com/mail/u/0/\#drafts?projector=1.

Kasumayanti, E., \& Busri, I.N. (2017). Faktor - faktor yang menyebabkan rendahnya peran ibu balita ke Integrated Health Post Desa Sumber Datar Wilayah Kerja Community Health Center Sungai Keranji Tahun 2016. Jurnal Doppler, 1(2), 15-26.

Maisara, E. (2014). Kajian faktor-faktor yang mempengaruhi kejadian pada balita di Kota Lhokseumawe (Tesis, USU). Diakses dari repository.usu. ac.id/handle/123456789/63616. 
apirah, M.R., Rahman, A., \& Tony, A. (2016). Faktor-faktor yang berhubungan dengan pemanfaatan pelayanan kesehatan di wilayah kerja Community Health Center Tambarana Kecamatan Poso Pesisir Utara Kabupaten Poso. Jurnal Pengembangan Kota, 4(1), 29-39.

Nasution, H.S., Siagian, M., \& Sibagariang, E.E. (2018). Hubungan pola makan dengan status gizi pada anak balita di wilayah kerja Community Health Center Medan Sunggal di Lingkungan XIII Kelurahan Sunggal Kecamatan Medan Sunggal Tahun 2018. Jurnal Kesehatan Masyarakat dan Lingkungan Hidup, 3(2), 48-58.

Notoatmodjo, S. (2012). Promosi kesehatan dan perilaku kesehatan. Jakarta: Rineka Cipta.

Notoatmodjo, S. (2014). Ilmu perilaku kesehatan. Jakarta: Rineka Cipta.

Novitasari, D., \& Puruhita, N. (2012). Faktor-faktor risiko kejadian gizi pada balita yang dirawat di RSUP Dr. Kariadi Semarang. Jurnal Kesehatan Masyarakat, 3(4). Diakses dari https://media.neliti.com/media/ publications/116266-ID-faktor-faktor-risikokejadian-gizi-buruk.pdf.

Nurdin, Ediana, D., \& Ningsih, N.S.D.M. (2019). Faktor-faktor yang berhubungan dengan partisipasi ibu balita ke Integrated Health Post di Jorong Tarantang. Jurnal Endurance, 4(1), 220-234.

Ratna, W., \& Sutrisno. (2013). Sosiologi dan antropologi kesehatan dalam aplikasinya di pendidikan kesehatan. Yogyakarta: Fitramaya.

Reihana, \& Duarsa, A.B.S. (2012). Faktor-faktor yang berhubungan dengan partisipasi ibu untuk menimbang balita ke Posyandu. Jurnal Kedokteran Yasri, 20(3), 143-157. Dikases dari academicjournal.yarsi.ac.id/index.php/jurnal-fkyarsi/article/view/167/103.

Saputra, W., \& Nurrizka, R.H. (2012). Faktor demografi dan risiko gizi buruk dan gizi kurang. Makara Kesehatan, 16(2), 95-101.

Sarlis, N., \& Ivanna, C. N. (2018). Faktor berhubungan denga status gizi balita di Community Health Center Sidomulyo Pekanbaru tahun 2016. Jurnal Endurance, 3(1), 146-152

Sartika, R. A. D. (2010). Analisis pemanfaatan program pelayanan kesehatan status gizi balita. Jurnal Kesehatan Masyarakat, 5(2), 78-83.

Wahyuni, N.S. (2012). Faktor-faktor yang berhubungan dengan pemanfatan pelayanan kesehatan di Community Health Center Sumber Rejo Kota Balikpapan Provinsi Kalimantan Timur Tahun 2012 (Skripsi, UI). Diakses dari: http://lib.ui.ac.id/bo/uibo/detail.jsp?id=20320041\&lokasi=lokal.

Wardani, D.P.K., Sari, S.P., \& Nurhidayah, I. (2015). Hubungan persepsi dengan perilaku ibu membawa balita ke posyandu. Jurnal Keperawatan Padjadjaran, 3(1), 1-10.

Wiyono, S. (2016). Epidemiologi gizi konsep dan aplikasinya. Jakarta: Sagung Seto 